\title{
Predictors of organoleptic quality of boiled and dried pulp of safou (Dacryodes edulis) and the shelf life of its fresh fruits
}

\author{
Sali Atanga Ndindeng ${ }^{1 *}$, Talle $^{2}$, Jude BigogA ${ }^{3}$, Joseph Kengue ${ }^{1}$, Jean-Marc Boffa ${ }^{4}$
}

\author{
${ }^{1}$ Fruit Program., Reg. Cent. \\ Agric. Res. Nkolbisson, Inst. \\ Agric. Res. Dev. (IRAD), \\ BP 2067, Yaoundé, Cameroon, \\ atangandi@yahoo.com \\ 2 Taless Dryfoods and \\ Equipments, BP 6011, \\ Yaoundé, Cameroon \\ 3 Dep. Biochem., Fac. Sci., \\ Univ. Yaounde-I, Yaoundé, \\ Cameroon \\ ${ }^{4}$ CIRAD, PCP Agroforesterie \\ Cameroun, UMR System, \\ Yaoundé, Cameroon
}

* Correspondence and reprints

Received 6 May 2011 Accepted 20 June 2011

Fruits, 2012, vol. 67, p. 127-136 (C) 2012 Cirad/EDP Sciences All rights reserved DOI: 10.1051/fruits/2012004 www.fruits-journal.org

RESUMEN ESPAÑOL, p. 136

\section{Predictors of organoleptic quality of boiled and dried pulp of safou (Dacryodes edulis) and the shelf life of its fresh fruits.}

Abstract - Introduction. The high intra-specific variation in safou traits and the perishable nature of the fruit hampers commercialization. Knowledge of the parameters that determine the acceptability of safou products and the shelf life of fresh fruits is critical for marketing and useful as a first step toward cultivar development. Materials and methods. Safou fruits of different pulp colors, skin colors and stages of ripening were collected from clones. Physicochemical and organoleptic analyses were performed on fresh and processed safou pulp, respectively, to elucidate parameters that could be used to determine the acceptability of boiled and dried safou pulp, and the shelf life of fresh fruits. Results and discussions. Our study demonstrated that the $\mathrm{pH}$ and color of raw pulp could be used to determine the acceptability of boiled and dried safou. Consumers preferred products which were not acidic (sour), with a nice aroma. There was a negative correlation between the $\mathrm{pH}$ of raw pulp and the acceptability of boiled and dried safou pulp. Likewise, there was a positive correlation between the color of raw pulp and the acceptability of boiled and dried safou pulp. These parameters were used to predict the taste of finished products. Polygalacturonase activity was higher in fully ripe and unripe fruits than in semi-ripe fruits. Polygalacturonase activity had a strong positive correlation with percentage loss of fully ripe fruit during storage and, as such, can also be used to predict the postharvest loss of safou. Conclusion. The $\mathrm{pH}$ and color of raw (uncooked) pulp of safou can be used to determine the taste and acceptability of boiled and dried pulp. Likewise, the activity of polygalacturonase in raw pulp can be used to predict its postharvest shelf life.

Cameroon / Dacryodes edulis / fruits / physicochemical properties / organoleptic properties / keeping quality / forecasting

Indicateurs de la qualité organoleptique de pulpe bouillie et séchée de safou (Dacryodes edulis) et durée de vie de ses fruits frais.

Résumé - Introduction. La grande variation intraspécifique des caractéristiques du safou et la nature périssable de ce fruit gênent sa commercialisation. La connaissance de paramètres aptes à déterminer l'acceptabilité des produits du safou et la durée de conservation des fruits frais serait essentielle pour le marketing et utile comme première étape vers le développement de cultivars. Matériel et méthodes. Les fruits de safou de différentes couleur de pulpe, couleur de peau et différents stades de maturation ont été échantillonnés à partir de différents clones. Des analyses physico-chimiques et organoleptiques ont été effectuées sur de la pulpe de safous frais et transformés, pour identifier les paramètres qui pourraient être utilisés pour déterminer d'une part l'acceptabilité de la pulpe de safou bouillie et séchée, d'autre part la durée de conservation des fruits frais. Résultats et discussion. Notre étude a démontré que le $\mathrm{pH}$ et la couleur de la pulpe brute pourraient être utilisés pour déterminer l'acceptabilité du safou bouilli et séché. Les consommateurs ont préféré des produits non aigres, à l'arôme agréable. Une corrélation négative est apparue entre le pH de la pulpe brute et l'acceptabilité de la pulpe de safou bouillie et séchée et une corrélation positive a été trouvée entre la couleur de la pulpe brute et l'acceptabilité de la pulpe de safou bouillie et séchée. Ces paramètres ont été utilisés pour prédire le goût des produits finis. L'activité de la polygalacturonase a été plus élevée dans les fruits bien mûrs et non mûrs que dans ceux demi-mûrs. Cette activité a montré une forte corrélation positive avec le pourcentage de perte de fruits bien mûrs pendant le stockage et, de ce fait, elle peut également être utilisée pour prédire la perte post-récolte du safou. Conclusion. Le pH et la couleur de la pulpe brute (crue) de safou peuvent être utilisés pour déterminer le goût et l'acceptabilité du produit bouilli et séché. De même, l'activité de la polygalacturonase dans la pulpe brute peut être utilisée pour prédire sa durée de vie post-récolte.

Cameroun / Dacryodes edulis / fruits / propriété physicochimique / propriété organoleptique / aptitude à la conservation / technique de prévision 


\section{Introduction}

Dacryodes edulis is an indigenous tree crop, previously growing in the wild, which has been domesticated and is widely cultivated in agroforestry systems in west and central Africa, the gulf of Guinea, the Democratic Republic of Congo and parts of Malaysia. The fruit of this tree (safou) is one of the most important agroforestry fruit products (AFFP) in terms of quantity and value, marketed in the humid forest zone of Africa [1, 2] and exported to Europe [3]. Due to the constant fluctuation in the price of cocoa and coffee in the world market and the high nutritional [4-7] and medicinal [8] value of safou, many farmers have adopted this crop both as a cash and food crop. Safou is consumed as boiled, roasted or dried pulp. The pulp and seed have also been shown to have extractable oil with high nutritional value [9]. Safou trade is increasing but has not yet gained full momentum because large-scale production has been hampered by farmers' inability to supply fruits with characteristics desired by the consumer and, more often, there is no consistency in size, taste, color, form, etc., which could be explained by the high intra-species tree-to-tree variation in fruit traits $[10,11]$. In addition, the highly perishable nature of the fruit, lasting 2-3 days at ambient temperature, also hampers marketing, and is why about $50 \%$ of the fruit produced is lost postharvest. Quality attributes and standards for safou have been proposed to stakeholders as a tool to facilitate the buying and selling of safou [12]. Furthermore, improved sanitation by regularly washing transportation containers, proper harvesting of fruits that minimizes injury, washing of fruits after harvest and treatment of fruits with SmartFresh ${ }^{\circledR}$ (1-methylcyclopropene) significantly increased fruit shelf life from 3 days to 2 weeks at $25^{\circ} \mathrm{C}$, with more than $95 \%$ of the fruits being of good quality [13].

Proper sorting of fruits at the time of harvest will have a considerable impact on marketing, as most consumers and safou processing units have expressed the desire to have fruits from the same tree or clone, and that are not acidic (sour) or slightly acidic. Immature and unripe safou have rose-colored skin, while fully ripe safou may be brownish, whitish, bluish or greenish depending on the cultivar. Semi-ripe safou has patches of rose and the skin color of the cultivar when it is fully ripe. The pulp of immature and unripe safou is cream white in color. Knowing which ripening stage is best for harvesting will have a significant effect on shelf life. Missang et al. reported that the activity of pectinmethylesterase remained constant during ripening, while that of cellulases and hemicellulases were very low or absent [14]. On the contrary, the activity of polygalacturonase (PG) increased drastically during ripening. We suspected that the activity of PG might be a good indicator of the shelf life of the fruit postharvest.

Consumers and processors of safou have expressed the need for a tool that could help them predict the acceptability of boiled and processed safou pulp directly from raw (uncooked) safou pulp and the shelf life of fresh fruits after harvest. Fruit size (large or small), shape (round or elongated) and skin color (white, brown, blue and greenish) are poor indicators of acceptability after boiling or processing as fruits of similar sizes, shapes or skin colors may show differences in sourness (acidity). Tools to predict the shelf life of fruits after harvest are non-existent, although such a tool is important for a highly perishable fruit like safou. Knowledge of parameters that determine the acceptability of safou products and shelf life of fresh fruits is critical for marketing and as a first step toward cultivar development.

\section{Materials and methods}

\subsection{Fruit samples}

For our study, safou was selected based on three morphological characteristics: pulp color, skin color and stage of ripening (figure 1). There were five distinct pulp colors (light green, whitish, ivory, light turquoise and $\tan$ ), four skin colors (brown, white, blue and greenish) and three ripening stages (unripe, semi-ripe and fully ripe). Fruits with different pulp and skin colors came from different trees but were harvested only at the 


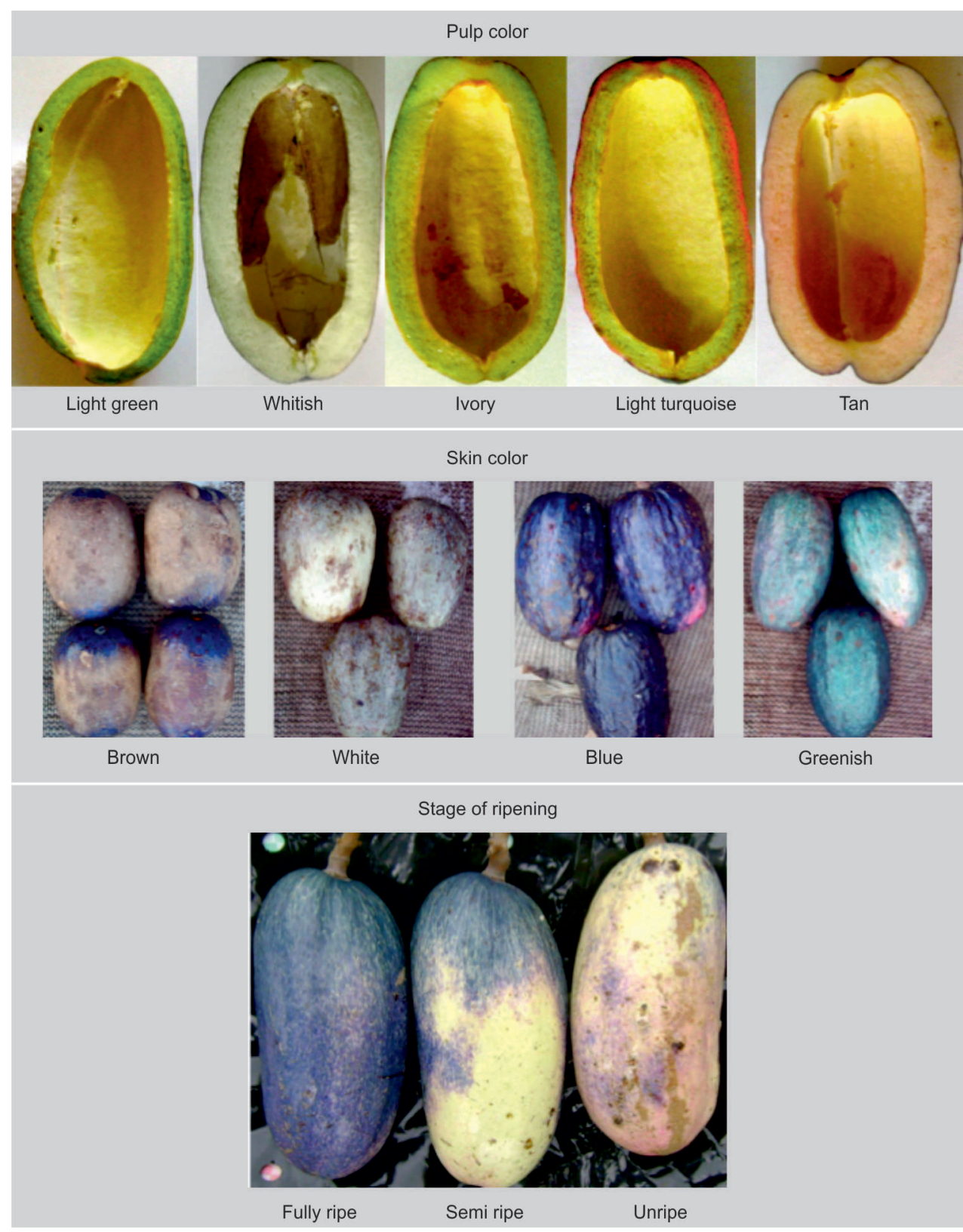

Figure 1.

Morphological characteristics of safou (Dacryodes edulis): pulp color, skin color and stages of ripening studied in Cameroon. fully ripe stage, while fruits at different stages of ripening came from the same tree. These trees are clones derived through marcotting and three replicate trees were randomly selected for each character. These clones are located at the Institute of Agricultural Research for Development (IRAD) experimental orchard in Nkolbisson, Yaoundé, Cameroon.

\subsection{Physical and chemical analysis}

Triplicate sets of fruit pulp of different pulp and skin colors were analyzed and the dry matter, crude fiber and ash content were determined using standard AOAC methods [15]. Total lipids were determined by the Soxhlet method of Bergeret [16], total sugars by the Anthron colorimetric method [17], 
and protein content was estimated from the total nitrogen content of the dried pulp using the Kjeldahl method and applying a conversion factor of 6.25 [18].

To determine the $\mathrm{pH}$ of raw and boiled pulp, an aliquot of $10 \mathrm{~g}$ of raw or boiled pulp was homogenized in a Waring blender. Safou pulp was boiled by immersing in boiling water for $3 \mathrm{~min}$, then the water was drained and the pulp covered and allowed to soften. After addition of $20 \mathrm{~mL}$ of distilled water, the mixtures were properly stirred. The $\mathrm{pH}$ was recorded using a Toadk Hm25R pH meter.

\subsection{Organoleptic analysis of raw pulp, boiled pulp and dried pulp}

For this experiment, boiled fruits were derived as explained above while dried samples were dried at the drying unit of Taless Dry Food and Equipment (Yaoundé, Cameroon). Fruit pulp was sliced into slices of $0.5 \mathrm{~mm}$ width and dried using a continuous hot air dryer $\left(35-40{ }^{\circ} \mathrm{C}\right.$ for $\left.24 \mathrm{~h}\right)$ constructed locally. Triplicate sets of fruit pulp of different pulp and skin colors were handed out to a panel of nine trained tasters to evaluate acidic taste, flavor and general acceptability. A range of answers was provided for each of the variables. Acidic taste of raw, boiled and dried pulp was classified as not acidic, slightly acidic, acidic or highly acidic. The flavor was classified as nice perfume, not perfumed or bad perfume. Finally, the tasters had to indicate whether the product was highly acceptable, acceptable or not acceptable. The tasters were isolated from each other and washed their mouths after each sample tasted.

\subsection{Determination of polygalacturonase activity}

For this experiment, 1-mm-thick slices of fruit pulp were used. The fruit categories used included different skin colors and different stages of ripening. Fifty grams (50 g) of this tissue were added to $100 \mathrm{~mL}$ of extraction buffer $(50 \mathrm{mM}$ sodium acetate trihydrate, $1 \mathrm{M}$ sodium chloride, $0.2 \%$ cysteine and 1\% polyvinylpyrrolidone-10) and homogenized in a Waring blender. The homogenate was filtered using a Miracloth. The residue was homogenized again in $50 \mathrm{~mL}$ of extraction buffer, filtered, and the two filtrates were mixed. The filtrate was stirred for $3 \mathrm{~h}$ and filtered again and then centrifuged at $10,000 \times \mathrm{g}$ for $30 \mathrm{~min}$ and the supernatant collected. Three-milliliter $(3 \mathrm{~mL})$ aliquots of the supernatant were dialyzed against $3 \mathrm{~L}$ of dialysis buffer $(0.5 \mathrm{M}$ sodium chloride) for $16 \mathrm{~h}$ to remove sugars. The samples in the bag were then collected and polygalacturonase activity was determined according to the Samogyi-Nelson method [19-21]. The results were expressed as units $\cdot \mathrm{mg}^{-1}$ solid where one unit of the enzyme will release $1.0 \mu \mathrm{mol}$ of reducing sugar measured as $D$-galacturonic acid from polygalacturonic acid per minute at $\mathrm{pH} 5.0$ and $30^{\circ} \mathrm{C}$.

In order to determine the links between polygalacturonase activity and shelf life, 30 fruits of different skin colors and different stages of ripening were spread in a clean dry place, which is a common storage practice. Every 2 days, one fruit was randomly selected from each group and assayed for polygalacturonase activity. In addition, the entire group was observed for loss of quality by recording the number of fruits that had lost quality because they had developed soft spots or changed color. Bad-quality fruits were counted and removed from the lot and the percent loss recorded.

\subsection{Statistical analysis}

The data were analyzed using the Statistical Package for Social Sciences (SPSS) version 10.1. The Student-Newman-Keuls procedure was used to compare the means in the different categories. The paired sample t-test was used to compare the $\mathrm{pH}$ of raw and boiled safou pulp. Discriminant function analysis was used to determine which physical or chemical parameter best discriminated the taste and acceptability of safou. Plots of these parameters and the quality of processed fruits were generated and their correlation values determined. Furthermore, linear regression analysis was used to propose an equation for the prediction of the taste of safou boiled pulp and dried 


\section{Table I.}

Physicochemical and organoleptic properties of fully ripe safou with different pulp colors. Values are means from three trees belonging to the same clone.

\begin{tabular}{|c|c|c|c|c|c|c|c|}
\hline \multirow{2}{*}{$\begin{array}{l}\text { Color } \\
\text { of raw pulp }\end{array}$} & Water $^{1}$ & Lipid $^{1}$ & Sugar $^{1}$ & Protein $^{1}$ & Dry matter ${ }^{1}$ & $\operatorname{Ash}^{1}$ & \multirow{2}{*}{$\begin{array}{l}\text { Crude fiber } \\
\left(\mathrm{g} \cdot 100 \mathrm{~g}^{-1}\right)\end{array}$} \\
\hline & \multicolumn{6}{|c|}{ (\%) } & \\
\hline Light green & $31.31 \pm 12.68 a b$ & $48.59 \pm 22.26 a$ & $48.93 \pm 20.50 a$ & $3.00 \pm 0.19 a$ & $91.39 \pm 8.94 a b$ & $3.04 \pm 2.94 a$ & $13.15 \pm 5.76 b$ \\
\hline Whitish & $25.96 \pm 13.12 \mathrm{a}$ & $51.34 \pm 8.90 \mathrm{a}$ & $45.47 \pm 9.72 \mathrm{a}$ & $3.00 \pm 0.27 b c$ & $89.95 \pm 5.44 \mathrm{a}$ & $3.17 \pm 1.52 a b$ & $9.91 \pm 3.84 \mathrm{a}$ \\
\hline Ivory & $27.10 \pm 8.98 a b$ & $47.56 \pm 9.86 a$ & $49.63 \pm 9.34 \mathrm{a}$ & $2.00 \pm 0.22 c$ & $92.54 \pm 2.34 a b$ & $2.70 \pm 0.70 \mathrm{a}$ & $13.93 \pm 4.22 b$ \\
\hline Light turquoise & $27.29 \pm 2.22 a b$ & $40.30 \pm 21.88 b$ & $52.67 \pm 11.56 \mathrm{a}$ & $3.00 \pm 0.28 b c$ & $91.56 \pm 2.10 a b$ & $4.01 \pm 3.92 c$ & $10.70 \pm 0.38 a$ \\
\hline Tan & $33.32 \pm 11.80 \mathrm{c}$ & $53.20 \pm 4.26 \mathrm{a}$ & $41.33 \pm 13.52 b$ & $3.00 \pm 0.32 b c$ & $93.24 \pm 2.38 c$ & $2.66 \pm 0.88 a$ & $10.67 \pm 2.76 \mathrm{a}$ \\
\hline
\end{tabular}

Means with different letters are significantly different at the 0.05 level of significance using the Student-Newman-Keuls test.

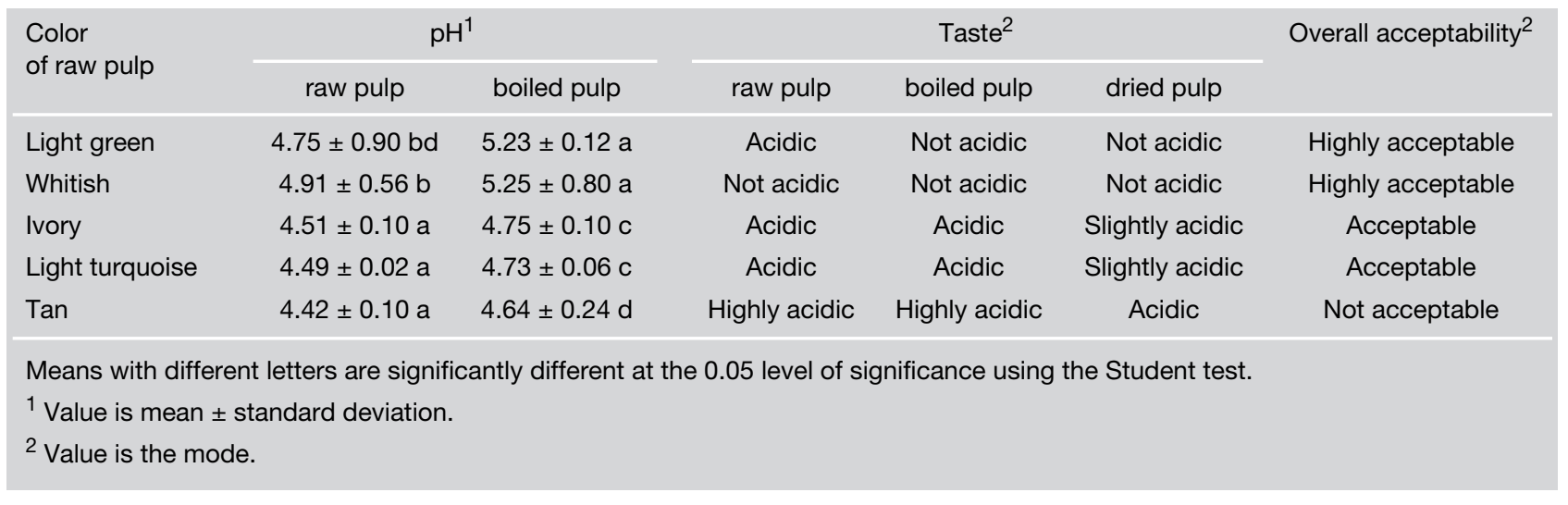

chips using the independent variable that best discriminated the taste and acceptability into distinct classes. The same analysis was used to predict the percent loss postharvest using polygalacturonase activity and days after storage as the independent variable. Pearson correlation analysis was also used to determine if a correlation exists between polygalacturonase activity and postharvest loss. All analysis was done at the 5\% significance level.

\section{Results and discussions}

\subsection{Color and $\mathrm{pH}$ of pulp of fully ripe safou and acceptability of boiled and dried safou pulp}

Fully ripe fruits with light green and whitish pulp color were highly acceptable both as boiled and dried safou and were not acidic after boiling or drying (table I). Fruit with ivory and light turquoise color were acceptable and their boiled and dried pulps were classified as acidic and slightly acidic, respectively. Fruits with tan pulp color were not acceptable and their boiled and dried pulp was classified as highly acidic and acidic, respectively. The $\mathrm{pH}$ of boiled pulp was not different between light green and whitish color pulp and their $\mathrm{pH}$ values were higher than in the other pulp colors. The $\mathrm{pH}$ of safou pulp generally increases after boiling $(P=0.001)$. Whitish raw pulp did not taste acidic; light green, ivory and light turquoise pulps were acidic, while tan pulp was highly acidic.

Fruits with tan-colored pulp had the highest water content $(33.32 \%)$, while whitish fruits had the least water content (25.96\%). Percent water, lipid, sugar, dry matter, ash and crude fiber content of fruit of different 


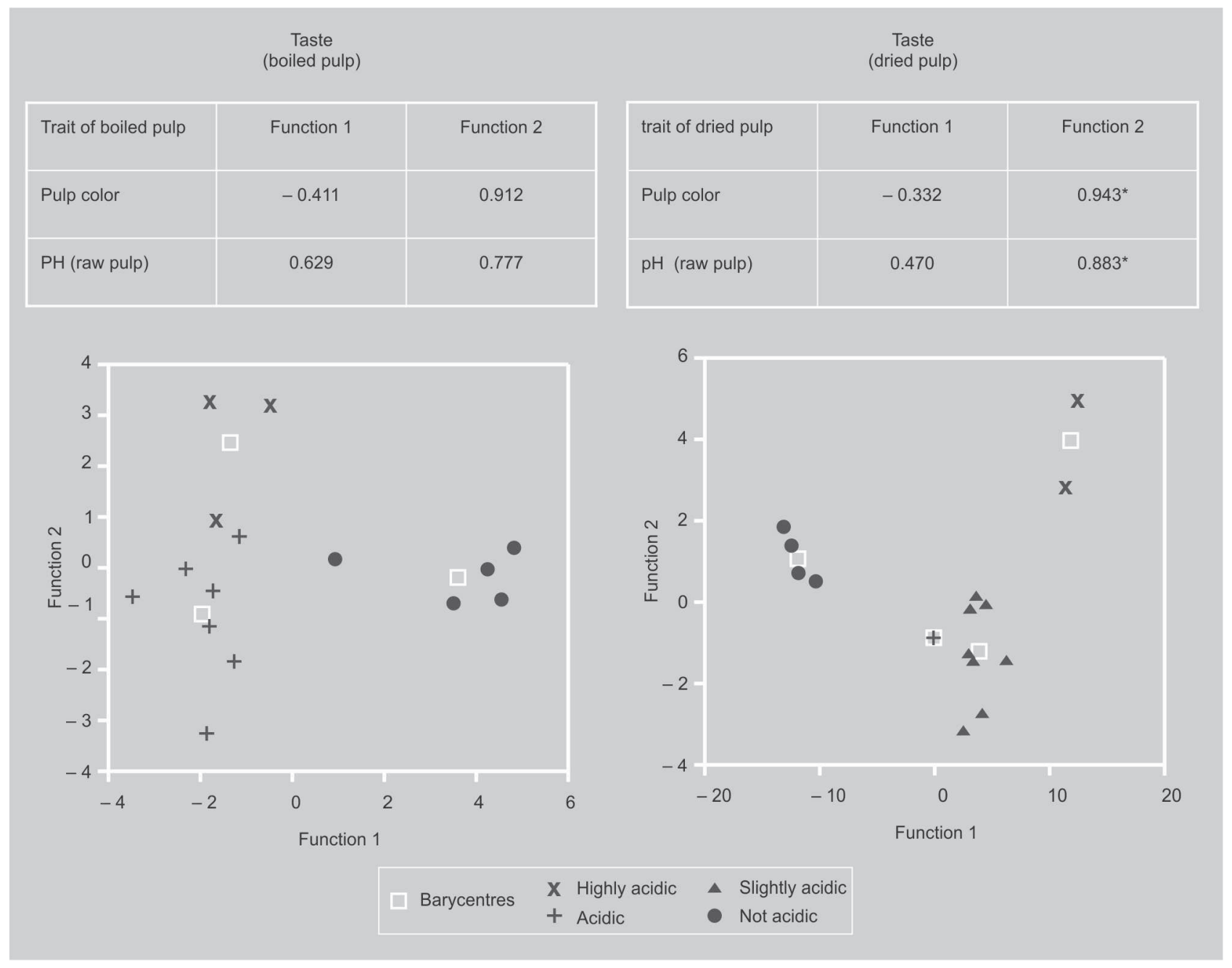

\section{Figure 2.}

Factors that determine the taste of boiled safou pulp and dried safou pulp ranked by absolute size of the correlation within the function and how they discriminate between the different taste groups. Values are means of each clone.

* Denotes significant correlation between the variable and the discriminant function at the 0.05 level of significance. pulp colors did not correlate with the acceptability of boiled or dried safou pulp, although the composition of these compounds makes safou a fruit with high nutritional and medicinal value. These results suggest that consumers of fresh safou and processing units can rapidly use the $\mathrm{pH}$ and color of raw pulp to screen safou that will be acceptable after boiling and drying, respectively. Although safou with tan pulp was not acceptable after either boiling or drying, this category of safou has been shown to be useful for the extraction of safou oil, both from seeds and pulp, and for the production of acidic pulp spread.

The color and $\mathrm{pH}$ of raw pulp ranked as the highest discriminant variables in terms of absolute size of the correlation within the discriminant function variables and effectively discriminated between the different taste categories of boiled safou (figure 2). Although percent protein content and $\mathrm{pH}$ of raw pulp ranked as the highest discriminant variables for the discrimination of different taste categories of dried safou, color and $\mathrm{pH}$ of raw pulp were used as discriminant variables for the different taste categories of dried safou (figure 2) because these two parameters are easily measurable under field conditions.

There was a negative correlation between the $\mathrm{pH}$ of raw safou pulp and the acceptability of boiled and dried safou pulp $(R=-0.547, P=0.001 ; R=-0.473, P=0.001)$ 

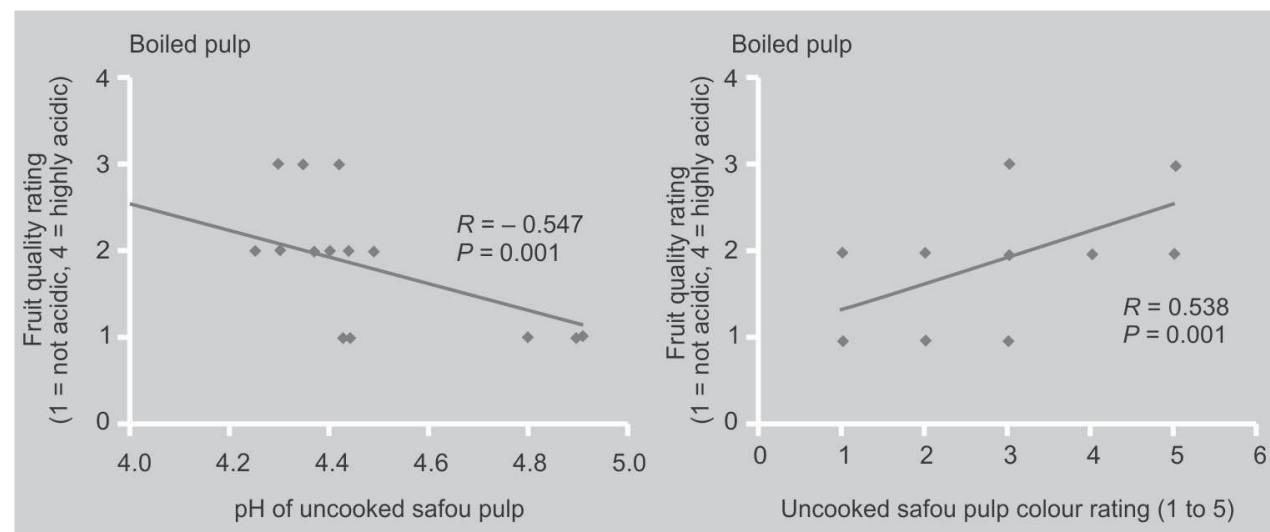

Figure 3.

Relationship between the $\mathrm{pH}$ and color of raw safou pulp and acceptability of boiled and dried safou pulp. The fruit quality (acceptability) was based on the acidity of fruits on a scale of 1 (not acidic) to 4 (highly acidic).
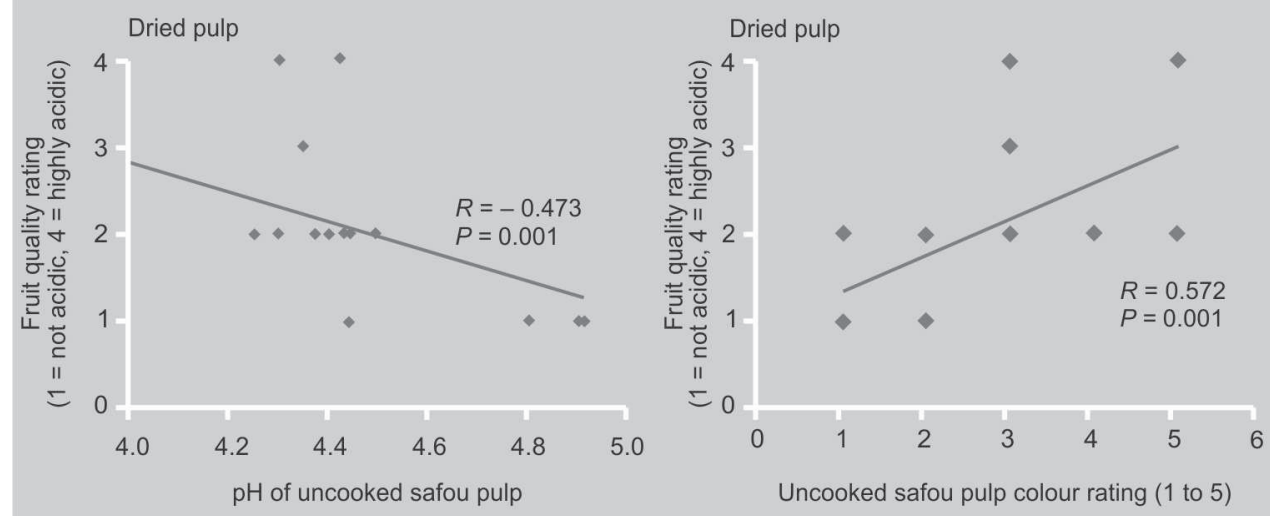

(figure 3). Likewise, a positive correlation was observed between the color of raw safou and the acceptability of boiled and dried safou pulp $(R=0.538, \quad P=0.001$; $R=0.572, P=0.001$ ) (figure 3 ). The $\mathrm{pH}$ and color of raw pulp can be used to predict the taste of boiled and dried safou using the regression model below. Since the variables are categorical, the categories were attributed numerical codes that were used for such predictions (table II). Taste of boiled and dried pulp could be measured as:

- taste of boiled pulp $=9.258-1.797(\mathrm{pH}$ of raw pulp) +0.233 (color of raw pulp) $(\mathrm{F}=31.82$, df = 2, $P=0.001)$;

- taste of dried pulp $=11.191-2.222(\mathrm{pH}$ of raw pulp) +0.306 (color of raw pulp) $(\mathrm{F}=28.96, \mathrm{df}=2, P=0.001)$.

We thus propose a quality system for safou acceptability based on safou $\mathrm{pH}$ and the color of raw safou pulp, bearing in mind that fruits that may not be acceptable when boiled or dried may be used for other rev- enue-generation purposes: for example, oil extraction.

\subsection{Postharvest polygalacturonase activity and shelf life of safou}

The polygalacturonase activity was higher in fully ripe and unripe fruits than in semiripe fruits. The mean difference in polygalacturonase activity was significant between fully ripe and semi-ripe (figure 4; LSD = 0.0017 units $\cdot \mathrm{mg}^{-1}$ solid, $P=0.04$ ) but not significant between fully ripe and unripe (LSD = 0.0005 units $\cdot \mathrm{mg}^{-1}$ solid, $P=0.52$ ) or semi-ripe and unripe fruits (LSD $=0.0012$ units $\cdot \mathrm{mg}^{-1}$ solid, $P=0.15)$. There was no significant change in polygalacturonase activity in unripe fruits during storage $(P>0.05)$. Polygalacturonase activity fluctuated in semi-ripe fruits during storage, with low levels at day 2 (0.002 units $\mathrm{mg}^{-1}$ solid), more than double at day $4\left(0.0045\right.$ units $\cdot \mathrm{mg}^{-1}$ solid) and a drop to day 2 levels at day 6 . 
Table II.

Numerical codes attributed to difference categories of safou pulp for the prediction of organoleptic quality of safou using a regression equation.

\begin{tabular}{lccccc}
\multicolumn{2}{c}{ Taste of boiled safou pulp } & \multicolumn{2}{c}{ Taste of dried safou pulp } & \multicolumn{3}{c}{ Color of raw safou pulp } \\
\cline { 1 - 4 } Categories & Numerical codes & Categories & Numerical codes & & \multicolumn{2}{c}{ Categories } & Numerical codes \\
\hline Not acidic & 1 & Not acidic & 1 & Whitish & 1 \\
Acidic & 2 & Slightly acidic & 2 & Light green & 2 \\
Highly acidic & 3 & Acidic & 3 & Light turquoise & 3 \\
& & Highly acidic & 4 & Ivory & 4
\end{tabular}

\section{Figure 4.}

Safou harvested at different stages of ripening show differences in

polygalacturonase activity (top) and differences in percentage fruit loss (bottom) during storage. * Denotes significant difference between the means of three independent measurements within a given time at the 0.05 level of significance.

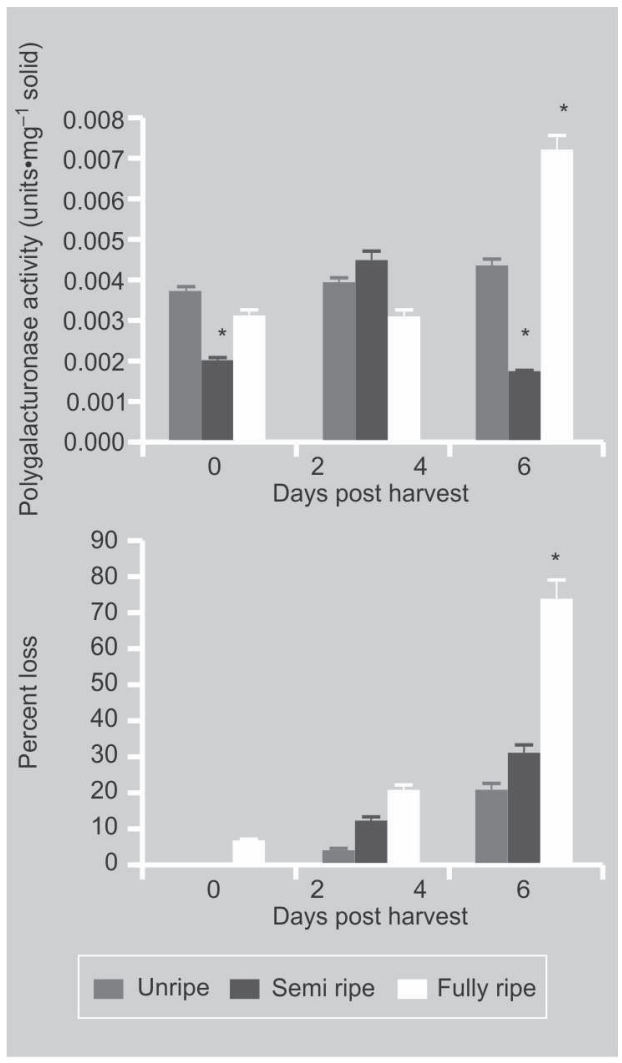

In fully ripe fruits, polygalacturonase activity is constant between the 2nd and 4th day after harvest $\left(0.0032\right.$ units $\cdot \mathrm{mg}^{-1}$ solid) but increases more than two-fold on the 6th day postharvest (0.007 units. $\mathrm{mg}^{-1}$ solid) (figure $4 ; \quad P=0.0001)$. The percentage loss increases during storage, with very high losses (75\%) recorded for fully ripe fruits compared with moderate losses (30\%) in semi-ripe fruits (figure 4). The results are consistent with observations made on tomato where plants with alterations in the polygalacturonase gene exhibit reduced enzyme activity and the fruits of such plants soften more slowly postharvest [22, 23]. Semi-ripe fruits are therefore preferable when fruits are destined for storage. However, semi-ripe safou fruits will need to be fully ripened before consumption or processing, since semi-ripe safou fruits taste acidic.

There was a strong correlation between percentage fruit loss and polygalacturonase activity for semi-ripe and fully ripe fruits from the same clone $(R=0.42, P=0.08)$. There was no difference in polygalacturonase activity (figure 5) or postharvest loss in fully ripe fruits of different clones (skin colors) during storage $(P>0.05)$, although this activity generally increases during storage $(P<0.05)$, as observed previously [14]. The regression model below was developed for the prediction of postharvest loss in fully ripe fruits using polygalacturonase activity: postharvest loss $=-80+4613.6$ (polygalacturonase activity in units $\cdot \mathrm{mg}^{-1}$ solid) +13.50 (days), with $\mathrm{F}=88.92$, $\mathrm{df}=35, P=0.0001$ ).

\section{Conclusions}

Safou is a highly perishable fruit (lasting 23 days at ambient temperature) and shows a high intra-species tree-to-tree variation in fruit traits. Consumers and processors of safou have expressed the need for a tool that 
could help them predict the acceptability of boiled and processed safou pulp directly from raw (uncooked) safou pulp and the shelf life of fresh fruits after harvest. Our study demonstrates that the color and $\mathrm{pH}$ of raw safou pulp can be used to predict the acceptability of boiled and dried safou pulp. In addition, the activity of polygalacturonase in safou pulp could be used to predict the postharvest shelf life of the fruit. Our work is the first of its kind on this fruit. The indicators of quality, acceptability and postharvest shelf life of safou that we present are easy to measure on raw safou pulp in the field and will be very useful for the buying and selling of the fruit. In addition, the results provide some clues as to what kinds of cultivars breeders should seek to develop in order to boost safou trade, that will undoubtedly increase safou production and boost rural economies.

\section{Acknowledgments}

This work received financial assistance from the International Foundation of Science, grant number E/3463-2, and a reagent grant through the Laboratory of Microbiology and Plant Pathology, Texas A\&M University, under the Norman E. Borlaug Fellowship Program. Sincere thanks also go to Stella Atanga Njebu, Ndanga Thomas and Otia Vitalis Suh for their technical assistance.

\section{References}

[1] Ndoye O., Ruiz-Pérez M., Eyebe A., The markets of non-timber forest products in the humid forest zone of Cameroon, Rural Dev. For. Netw. Pap. 22c, Lond., U.K., 1997, 22 p.

[2] Awono A., Ndoye O., Schreckenberg K., Tabuna H., Isseri F., Temple L., Production and marketing of safou (Dacryodes edulis) in Cameroon and internationally: Market development issues, For. Trees Livelihoods 12 (2002) 125-147.

[3] Tabuna H., Le marché des produits forestiers non ligneux de l'Afrique centrale en France et en Belgique: Produits, acteurs, circuits de distribution et débouchés actuels, Cent. Int. For. Res., No. 19, Bogor, Indones., 1999, 31 p.

[4] Silou T., Rocquelin G., Mouaragadja I., Gallon G., Chemical composition and nutritional characteristics of safou of Cameroon, the

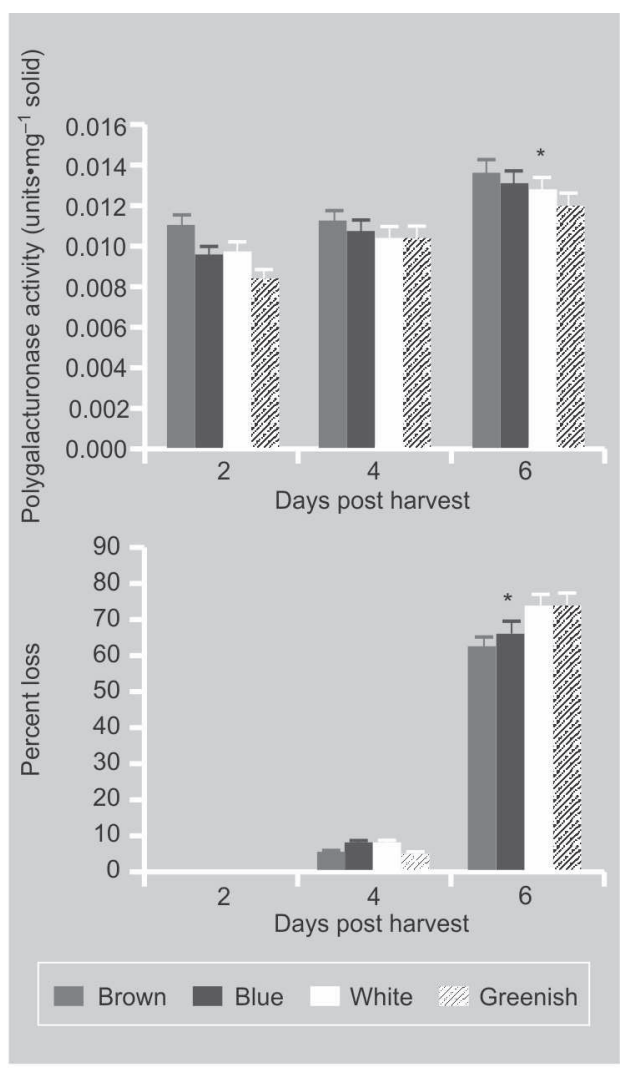

Figure 5.

Polygalacturonase activity in fully ripe safou of different skin colors (top) and percentage loss during storage (bottom). * Denotes significant increase in the mean of three independent measurements on the 6th day of observation compared with the 2 nd and 4 th days at the 0.05 level of significance.
Congo-Brazzaville, the Congo-Kinshasa and Gabon, Riv. Ital. Sostanze Grasse 79 (2002) 177-182.

[5] Omogbai B.A., Ojeaburu S.I., Nutritional composition and microbial spoilage of Dacryodes edulis fruits vended in Southern Nigeria, Sci. World J. 5 (2010) 5-10.

[6] Nwosuagwu U.H., Ngozika C.O., Chiaka C.N., The chemical properties of African pear pulp at different stages of fruit development, Int. NGO J. 4 (2009) 380-385.

[7] Onuegbu N.C., Ihediohanma N.C., Some proximate analysis of african pear (Dacryodes edulis), J. Appl. Sci. Environ. Manag. 12 (2008) 83-85.

[8] Simons A.J., Leakey R.R.B., Tree domestication in tropical agroforestry, Agroforestry Syst. 6 (2004) 167-181.

[9] Dzondo-Gadet M., Nzikou J.M., Etoumongo A., Linder M., Desobry S., Encapsulation and storage of safou pulp oil in 6DE maltodextrins, Process Biochem. 40 (2005) 265-271.

[10] Leakey R.R.B., Tchoundjeu Z., Schreckenberg K., Shackleton S.E., Shackleton C.M., Agroforestry tree products(AFTPs): Targeting poverty reduction and enhanced livelihoods, Int. J. Agric. Sustain. 3 (2005) 1-23. 
[11] Ndindeng S.A., Bella-Manga, Kengue J., Talle, Lewis D.L., Quality standards for Dacryodes edulis (safou), Res. Rep. Int. Cent. Underutil. Crops, No. 5, Columbo, Sri Lanka, 2008, 22 p.

[12] Ndindeng S.A., Kengue J., Mbacham W.F., Titanji V.P.K., Bella-Manga, Effects of 1methylcyclopropene treatments on the shelf life and quality of safou [Dacryodes edulis (G. Don) H. J. Lam], For. Trees Livelihoods 17 (2007) 75-89.

[13] Missang C.E., Baron A., Renard C.M.G.C., Cell wall-degrading enzymes and changes in cell wall polysaccharides during ripening and storage of bush butter [Dacryodes edulis (G. Don) H.J. Lam] fruit, J. Hortic. Sci. Biotechnol. 79 (2004) 797-805.

[14] Anon., Official methods of analysis, AOAC, 13th ed., William Herwitz, Wash., U.S.A., 1980, pp. 130-131.

[15] Kinkéla T., Kama-Niamayoua R., Mampouya D., Silou T., Variations in morphological characteristics, lipid content and chemical composition of safou [Dacryodes edulis (G. Don) H.J. Lam] according to fruit distribution. A case study, Afr. J. Biotechnol. 5 (2006) 1233-1238.

[16] Bergeret B., La chimie analytique dans un laboratoire d'outre-mer. Organisation du laboratoire: étude des techniques d'ana- lyses employées au laboratoire de la section I'IRCAM-ORSTOM, IRCAM, 1955, 56 p.

[17] Montreuil J., Spik G., Tollier M.T., Dosages colorimétriques des glucides, in : Deymié B., Multon J.-L., Simon D. (Eds.), Techniques d'analyse et de contrôle dans les industries agro-alimentaires, no. 4, Tech. \& Doc. Lavoisier, Paris, Fr., 1981, pp. 85-143.

[18] Godon B., Loisel W., Protéines, in : Deymié B., Multon J.-L., Simon D. (Eds.), Techniques d'analyse et de contrôle dans les industries agro-alimentaires, no. 4, Tech. \& Doc. Lavoisier, Paris, Fr., 1981, pp. 187-205.

[19] Nelson N., A photometric adaptation of the Somogyi method for the determination of glucose, J. Biol. Chem. 153 (1944) 375-380.

[20] Somogyi M., A new reagent for the determination of sugars, J. Biol. Chem. 160 (1945) 61-68.

[21] Somogyi M., Notes on sugar determination, J. Biol. Chem. 195 (1952) 19-23.

[22] Hamilton A.J., Sense and antisense inactivation of fruit ripening genes in tomato, Curr. Top. Microbiol. Immunol. 197 (1995) 77-89.

[23] Schuch W., Kanczler J.M., Robertson D., Hobson G., Tucker G., Grierson D., Bright S., Bird C., Fruit-quality characteristics of transgenic tomato fruit with altered polygalacturonase activity, Hortic. Sci. 26 (1991) 15171520.

\section{Indicadores de la calidad organoléptica de la pulpa hervida y secada de safu (Dacryodes edulis) y vida útil de sus frutos frescos.}

Resumen - Introducción. La gran variación intraespecífica de las características del safu, así como la naturaleza perecedera de dicho fruto representan un obstáculo para su comercialización. Conocer los parámetros que permiten determinar la aceptabilidad de los productos de safu y el tiempo de conservación de los frutos frescos sería esencial para el marketing y útil como primera etapa del desarrollo de cultivares. Material y métodos. A partir de diferentes clones, se sacaron muestras de frutos de safu con un color de pulpa, un color de piel y un estado de maduración diferentes. En la pulpa de safus frescos y transformados se efectuaron análisis físico-químicos y organolépticos, de modo a identificar los parámetros que podrían emplearse para determinar, por un lado, la aceptabilidad de la pulpa de safu hervida y secada y, por otro lado, el tiempo de conservación de los frutos frescos. Resultados y discusión. Nuestro estudio demostró que el pH y el color de la pulpa en bruto podrían emplearse para determinar la aceptabilidad del safu hervido y secado. Los consumidores prefirieron los productos no amargos y de aroma agradable. Entre el pH de la pulpa en bruto y la aceptabilidad de la pulpa de safu hervida y secada surgió una correlación negativa. Asimismo, entre el color de la pulpa en bruto y la aceptabilidad de la pulpa de safu hervida y secada se encontró una correlación positiva. Estos parámetros se emplearon para predecir el sabor de los productos acabados. La actividad de la poligalacturonasa fue mayor en los frutos muy maduros e inmaduros que en aquéllos semi-maduros. Dicha actividad presentó una positiva correlación con el porcentaje de pérdida de frutos muy maduros durante el almacenaje $\mathrm{y}$, por lo tanto, puede emplearse igualmente para predecir la pérdida posterior a la cosecha del safu. Conclusión. Se pueden emplear el pH y el color de la pulpa en bruto (crudo) de safu para determinar el sabor y la aceptabilidad del producto hervido y secado. Asimismo, la actividad de la poligalacturonasa en la pulpa en bruto puede emplearse para predecir su vida útil después de la cosecha.

Camerún / Dacryodes edulis / frutas / propiedades fisicoquímicas / propiedades organolépticas / aptitud para la conservación / técnicas de predicción 